\section{Cytotoxicity of $5 \%$ ethanol extracts of moringa oleifera leaf as an alternative of root canal irrigant to fibroblast BHK-21 cell culture}

\author{
Juni J. Nugroho," Asrianti, Aries C. Trilaksana, Nurhayaty Natsir, \\ Christine A. Rovani, Noor Hikmah
}

\title{
Abstract
}

Objective: The purpose of this study was to determine the cytotoxicity of $5 \%$ ethanol extracts of Moringa oleifera leaf based on the percentage of fibroblast cell life after exposure to $5 \%$ ethanol extracts of Moringa oleifera leaf.

Material and Methods: This study was an experimental laboratory with posttest only control group design. The extract was macerated using ethanol. Toxicity tested using the MTT Assay method. The fibroblast cells distributed in 96 well microplate were divided into 5 treatment groups. Group I as a negative control containing culture media, group II as a positive control containing cells in culture media, group III $5 \%$ ethanol extracts of Moringa leaf, group IV $2 \%$ chlorhexidine solution and group V 2.5\% $\mathrm{NaOCl}$ solution. The percentage of cell life is calculated from the optical density value of the ELISA reader. Data were analyzed using the Kruskal Wallis test followed by the Post Hoc test using the Mann Whitney test.

Results: The results showed the percentage of life of fibroblast cells after exposure to $5 \%$ ethanol extracts of Moringa oleifera leaf $=33.31 \%, 2.5 \% \mathrm{NaOCl}=28.89 \%$ and $2 \%$ chlorhexidine $=$ $39.37 \%(p=0.000, p<0.05)$.

Conclusion: $5 \%$ ethanol extracts of Moringa oleifera and $2 \%$ chlorhexidine were moderately toxic to fibroblast cells while $2.5 \%$ $\mathrm{NaOCl}$ was strongly toxic $(p=0.004, p<0.05)$.
Department of Conservative Dentistry, Faculty of Dentistry, Hasanuddin University, Makassar, Indonesia
*Correspondence to: Juni J. Nugroho, Department of Conservative Dentistry, Faculty of Dentistry, Hasanuddin University, Makassar, Indonesia

jektijuni@unhas.ac.id ; jektijuni@yahoo.co.id

Received: 28 February 2019 Revised: 19 November 2020 Accepted: 30 December 2020 Available Online: 1 April 2021

Keywords: Citotoxicity, Fibroblast cells, Moringa oleifera leaf

Cite this Article: Nugroho JJ, Asrianti, Trilaksana AC, Natsir N, Rovani CA, Hikmah N. 2021. Cytotoxicity of $5 \%$ ethanol extracts of moringa oleifera leaf as an alternative of root canal irrigant to fibroblast BHK- 21 cell culture. Journal of Dentomaxillofacial Science 6(1): 39-41. D0I:10.15562/ jdmfs.v6i1.1105

\section{Introduction}

Root canal treatment as an effort to keep the teeth remaining in the arch and functioning properly consists of three stages, namely: preparation, disinfection and filling of the root canal. ${ }^{1}$ From the three stages of root canal treatment, irrigation during preparation is an important factor which determine the success of root canal treatment and healing of periapical tissue. ${ }^{1-3}$

During root canal irrigation, irrigating material might diffused and extruded into periapical tissue and periodontal ligaments causing irritation. The most important component of this tissue is fibroblast cells, which found in large numbers in the coronal pulp and are the basic substances composing the periapical tissues and periodontal ligaments. ${ }^{4}$

So far, the most commonly used root canal irrigating material is sodium hypochlorite $(\mathrm{NaOCl})$ because of its antimicrobial activity and its ability to dissolve organic tissue. However, $\mathrm{NaOCl}$ is a potential irritant for periapical tissue. This is certainly in contrary with one of the required properties for a root canal irrigating material which has to be nontoxic. ${ }^{5,6} \mathrm{In}$ addition to $\mathrm{NaOCl}$, another irrigating material which frequently used is chlorhexidine gluconate (CHX). Chlorhexidine gluconate has antiseptic property and effectively controlling dental biofilms in patients with periodontal disease. $^{7-9}$

At present, there is no ideal root canal irrigation material. Therefore, natural materials which can be developed as an alternative to root canal irrigating materials are needed. ${ }^{8}$ One of them is Moringa oleifera leaf. ${ }^{10}$ This plant contains a unique compound of glucosinolate and isothiocyanate which has antibacterial property. ${ }^{11-14}$ In addition, there are secondary metabolites such as flavonoids, saponins, alkaloids, and tannins which also have antibacterial property. ${ }^{14,15}$ The results of previous studies showed that the 5\% ethanol extracts of Moringa oleifera leaf was effective against Enterococcus faecalis bacteria which known as the most resistant bacteria in root canal treatment. ${ }^{16}$ Therefore, researchers wanted to determine the biocompatibility of ethanol extracts of Moringa oleifera leaf as a potential material and an alternative to root canal irrigating material by testing its toxicity against fibroblast cell culture. 


\section{Material and Methods}

This research is a laboratory experimental study with posttest only control gropu design. The research was conducted at the pharmacy Laboratory of the Makassar School of Pharmacy (STIFA) and the Farma Veterinary Center Laboratory (PUSVETMA) Surabaya. Research permission was obtained from the health research ethics committee of the Dental and Oral Hospital of the Faculty of Dentistry Hasanuddin University. The study was started by making extracts by maceration using ethanol, ${ }^{16}$ then carrying out toxicity tests using the MTT assay method. ${ }^{17}$ Fibroblast cells that had been distributed in 96-well microplate were divided into five treatment groups. Group I as negative control containing culture media, group II as positive control containing cells in culture media, group III $5 \%$ ethanol extracts of moriga leaf (EEML), group IV $2 \% \mathrm{CHX}$ and group V $2.5 \% \mathrm{NaOCl}$ solution. The percentage of cell life is calculated using a formula from Khoswanto. ${ }^{18}$ based the classification of the number of cells living according to Bajrami et al. ${ }^{2}$ data were statistically analyzed usng the Kruskal Wallis test then followed by the Post Hoc test using the Mann Whithney test.

\section{Results}

The results of the calculation of the percentage of cell life showed that the 5\% ethanol extracts of Moringa oleifera and 2\% chlorhexidine are moderately cytotoxic while $2.5 \% \mathrm{NaOCl}$ is strongly cytotoxic. The Kruskal Wallis test for the results of the calculation of the percentage of cell life shows the value of $p=0.000(p<0.05)$, which means that there are differences in the average value of cell life between treatments table 1.

The Mann Whitney test results showed a significant difference in the average percentage of cell life between 5\% EEML and 2.5\% NaOCl, between 2.5\% $\mathrm{NaOCl}$ and 2\% CHX, and between 5\% EEML and $2 \%$ CHX groups $(\mathrm{p}=0.004<0.05)$ table 2.

\section{Discussion}

The results of this study indicate that the 5\% ethanol extracts of Moringa oleifera leaf is moderately cytotoxic but at the toxicity level below the $2.5 \%$ $\mathrm{NaOCl}$. Likewise, $2 \%$ chlorhexidine has a lower toxicity than $2.5 \% \mathrm{NaOCl}$. The results of this study are in line with the research of Anwar et al. ${ }^{11}$ which concluded that Moringa oleifera leaf extract has a toxic effect. Likewise, that alkaloid and flavonoid compounds at certain levels have a potential to induce acute toxicity. ${ }^{11}$

Toxic properties of Moringa oleifera leaf extract are generated by its glucosinolate compounds. Glucosinolate is known to be non-toxic, however its degradation products which produced by the enzyme myrosinase (thioglucosidase) breaks down the sulfur-glucose bonds to form the toxic isothiocyanate (ITCS) compounds. According to Karim et al. ${ }^{19}$ glucosinolate compounds found in Moringa leaf able to induce apoptosis. ${ }^{19}$

In another study evaluating Moringa leaf toxicity, Ambi et al. ${ }^{20}$ concluded that Moringa leaf is safe to

Table 1 Percentage of cell life from each treatment group

\begin{tabular}{llll}
\hline Groups & & $\begin{array}{c}\text { Cell Life } \\
\text { mean } \pm \text { SD }\end{array}$ & p value \\
\hline $5 \% \mathrm{EEML}$ & 6 & $33.31 \pm 2.07$ & \\
$2.5 \% \mathrm{NaOCl}$ & 6 & $24.89 \pm 0.82$ & 0.000 \\
$2 \% \mathrm{CHX}$ & 6 & $39.37 \pm 3.61$ & \\
\hline
\end{tabular}

Kruskal Wallis test: $\mathrm{p}<0.05$; significant

Table 2 Comparison of mean cell life values between treatment groups

\begin{tabular}{lccc}
\hline Groups & & Mean \pm SD & p value \\
\hline $5 \% \mathrm{EEML}$ & $2.5 \% \mathrm{NaOCl}$ & $24.89 \pm 0.82$ & 0.004 \\
& $2 \% \mathrm{CHX}$ & $39.37 \pm 3.61$ & 0.004 \\
$2.5 \% \mathrm{NaOCl}$ & $5 \% \mathrm{EEML}$ & $33.31 \pm 2.07$ & 0.004 \\
& $2 \% \mathrm{CHX}$ & $39.37 \pm 3.61$ & 0.004 \\
$2 \% \mathrm{CHX}$ & $5 \% \mathrm{EEML}$ & $33.31 \pm 2.07$ & 0.004 \\
& $2.5 \% \mathrm{NaOCl}$ & $24.89 \pm 0.82$ & 0.004 \\
\hline
\end{tabular}

Mann Whitney test; $\mathrm{p}<0.05$; significant 
use in medicines or foods. Likewise, the results of the toxicological evaluation of Moringa leaf in wistar rats conducted by Olayemi et al. ${ }^{21}$ revealed that Moringa leaf extract was not toxic. This statement is also in accordance with the results of a study by Babychan et al. ${ }^{22}$ which concluded that Moringa leaf extract showed high antioxidant properties. Moringa leaf extract is rich in natural antioxidants, among others: flavonoids, tannins, saponins and alkaloids which are able to reduce oxidative stress and maintain cell function. ${ }^{20-22}$

A review of the safety and effectiveness of moringa leaf by Stohs et al. ${ }^{23}$ stated that moringa leaf is safe to use in food products for human nutrition. Moringa leaf extract shows great antioxidant activity. Various studies in animals showed a high level of safety and no side effects were reported. According to Muhammad et al. ${ }^{24}$ diluted fraction of moringa leaf significantly increases proliferation, viability and migration of human dermal fibroblast (HDF). These findings indicate that moringa leaf contains the vicenin-2 compound which able to accelerate wound healing in vitro. Flavonoid vcompounds identified in moringa leaf extract are known to be useful in treatment for wound healing and this is related to their antioxidant properties. ${ }^{23,24}$ Based on the results of the analysis, it can be concluded that the ethanol extracts of moringa oleifera leaf and chlorhexidine are moderately toxic to fibroblast cells, but at the toxicity level below the $2.5 \% \mathrm{NaOCl}$. Hence, it can be considered as an alternative root canal irrigating material.

\section{Acknowledgment}

Thank you for the support Faculty of Dentistry Hasanuddin University.

\section{Conflict of Interest}

The authors report no conflict of interest.

\section{References}

1. Trilaksana AC, Saraswati A. Efficacy of green tea leaf extract (camellia sinensis) with $\mathrm{NaOCl} 2.5 \%$ against enterococcus faecalis as an alternative solution for root canal irrigation. J Dentomaxillofac Sci 2017;1: 58-62.

2. Bajrami D, Hoxha V, Gotduysus O, et al. Cytotoxic effect of endodontic irrigants in vitro. Med Sci Basic Res 2014;20: 22-26.

3. Wahyuniwati, Nugroho JJ, Trilaksana AC, et al. Microhardness characteristics values of root canal dentin after application with different types of EDTA. J Dentomaxillofac Sci 2016;1: 49-52.

4. Mirhadi H, Azar MR, Abbaszadegan A, et al. Cytotoxicity of chlorhexidine-hydrogen peroxide combination in different concentrations on cultured human periodontal ligament fibroblasts. Dent Res J 2014;11: 645-648.
5. Alagl AS, Bedi S, Almas K. Phytosolutions for enterococcus faecalis in endodontics: an update. OHDM 2016;15: 332-335.

6. Mistry KS, Sanghvi Z, Parmar G, et al. Comparative evaluation of antimicrobial activity of herbal extracts with $5.25 \%$ sodium hypochlorite against multispecies dentinal biofilm. Saudi Endod J 2016;6: 71-76.

7. Goncalves LS, Rodrigues RCV, Andrade JCVA, et al. The effect of sodium hypochlorite and chlorhexidine as irrigant solutions for root canal disinfection: a systematic review of clinical trials. J Endod 2016: 1-6.

8. Mattulada IK. The choice of intracanal medicament between visits is rational. Dentofasial J 2010;9: 63-69. (In Indonesia)

9. Tanumihardja M. Root canal Irrigation Solution. Dentofasial J 2010;9: 108- 115. (In Indonesia)

10. Mathew T, Shetty A, Hegde MN. Comparison of antimicrobial activities of moringa oleifera leaf, propolis, $2 \%$ clo-rhexidine gluconate and mtad on e. faecalis - an in- vitro study. RJPBC 2014;5: 163-173.

11. Anwar S, Yulianti E, Hakim A, et al. Toxicity test of aquades extract (room temperature) and hot distilled water $\left(70^{\circ} \mathrm{C}\right)$ Moringa oleifera Lam leaves against shrimp larvae (artemia salina leach). Alchemy 2014;1: 84-92. (In Indonesia)

12. Tejas GH, Umang JH, Payal BN, et al. A panoramic view on pharmacognostic, pharmacological, nutritional, therapeutic, and prop[hylactic, values of Moringa oleifera lam. IRJP 2012;3: 1-7.

13. Pandey A, Pandey RD, Tripathi P, et al. Moringa oleifera lam. (sahijan) - a plant with a plethora of diverse therapeutic benefits: an updated retrospection. Med Aromat Plants 2012;1: 1-8.

14. Peixoto JRO, Silva GC, Costa RA, et al. In vitro antibacterial effect of aqueous and ethanolic Moringa leaf extracts. Asian Pac J Trop Med 2011: 201-204.

15. Rao PK, Rao DB, Kiran R, et al. In vitro antibacterial activity of Moringa Oleifera against dental plaque bacteria. J Pharm Res 2011;4: 695-697.

16. Suriaman E, Khasanah S. Screening for the antibacterial activity of moringa oleifera leaves, sea bidara leaves (strychnos ligustrina blume), and amoxicillin against staphylococcus aureus pathogenic bacteria. J Biota 2017;3: 21-26. (In Indonesia)

17. Meizarini A. The cytotoxicity of cyanoacrylate restorations in various ratio of powder and liquid using MTT assay. Maj Ked Gigi (Dent J) 2005;38: 20-24. (In Indonesia)

18. Khoswanto C. Cytotoxicity test of $50 \%$ citric acid conditioner dentin using MTT assay. Dent J 2008;41: 103-106.

19. Karim ANA, Ibrahim M, Kantayya SB, et al. Moringa oleifera Lam: targeting chemoprevention. Asian Pac J Cancer Prev 2016;17: 3675-3686.

20. Ambi AA, Abdurahman EM, Katsayal UA, et al. Toxicity evaluation of moringa oleifera leaves. Int J Pharmaceutic Res Inn 2011;4: 22-24.

21. Olayemi AT, Olanrewaju MJ, Oloruntoba AC. Toxicological evaluation of Moringa oleifera Lam seeds and leaves in wistar rats. Pharmacogn Comn 2016;6: 100-111.

22. Babychan N, Reshma JK, Mole SL et al. Analysis of antioxidant properties of moringa oleifera Lam in urban and coastal area. IJAR 2017;3: 1098-1101.

23. Stohs SJ, Hartman MJ. Review of the safety and efficacy of moringa oleifera phytother. Res 2015;29: 796-804.

24. Muhammad AA, Pauzi NAS, Arulselvan P, et al. In Vitro wound healing potential and identification of bioactive compounds from Moringa oleifera Lam. BioMed Res Int 2013: 1-11

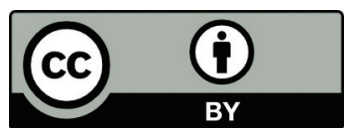

This work is licensed under a Creative Commons Attribution 